\title{
A Review on Ethnobotanical, Phytochemical and Pharmacological Profile of Pinus wallichiana A.B. Jacks.
}

\section{Dwaipayan Sinha*}

\section{Dwaipayan Sinha*}

Department of Botany, Government General Degree College, Mohanpur, Paschim Medinipur

West Bengal-721436, INDIA.

\section{Correspondence}

\section{Dwaipayan Sinha}

Department of Botany, Government General Degree College, Mohanpur, Paschim Medinipur, West Bengal-721436, INDIA.

Phone no: 9007709999

E-mail: dwaipayansinha@hotmail.com History

- Submission Date: 10-02-2019;

- Review completed: 02-05-2019;

- Accepted Date: 10-05-2019.

DOI : 10.5530/pj.2019.11.100

Article Available online

http://www.phcogj.com/v11/i4

\section{Copyright}

(C) 2019 Phcogj.Com. This is an openaccess article distributed under the term of the Creative Commons Attribution 4.0 International license.

\begin{abstract}
Introduction: Pinus wallichiana A.B. Jacks. or the blue pine is one of the important conifer that grows all along the Himalayan range from Afghanistan in the west to Myanmar and China in the east covering the Himalayan regions of Pakistan, Nepal and India. It is found in the upper region of the mountains and often remains associated with other gymnosperms. The plant is of immense ethnobotanical relevance and finds extensive use among the people inhabiting the mountainous region. They are primarily valued for its timber and used for construction and infrastructural purposes. Medicinally the plant is very much important. Throughout the Himalayan region the plant is used for the cure of a number of diseases including treatment of fever, cough and cold, bone fracture, healing of injury and wounds, rheumatic pain, arthritis, inflammations etc. The plant is rich in terpenoids and flavonoids all of which possess strong antioxidant properties. Methods: Extensive literature survey was made in the internet with pubmed, google scholar forming the search platform to illustrate the traditional usage of the plant among inhabitants of various regions of Himalayas. Informations of traditional usage, chemical constituents and selected pharmacological activities of the plant were pooled from available research papers to frame the review. Results and Outcome: In this review, an attempt has been made to compile the ethnobotanical usage of Pinus wallichiana, its phytochemistry and pharmacological activity highlighting its potentiality as a cheap and affordable source of drugs for the benefit of population of Indian subcontinent and adjoining areas. Key words: Terpenoids, Flavonoids, Conifer, Himalaya, Arthritis, Antioxidant.
\end{abstract}

\section{INTRODUCTION}

Pinus wallichiana A.B. Jackson or the blue pine is one of the species of Pinus that is native to Himalayan ranges, Karakoram range and Hindu Kush Mountains. The extensive and luxuriant growth of this plant is found all along the Himalayan ranges starting from eastern Afghanistan, extending all the way through Pakistan, Indian, Nepal, Bhutan, Myanmar and China with an altitudinal range from 1800 meters to 4300 meters. ${ }^{1}$ Globally the species is distributed between $68^{\circ} \mathrm{E}$ to $100^{\circ} \mathrm{E}$ longitudes and $25^{\circ} \mathrm{N}$ to $36^{\circ} \mathrm{N}$ latitudes. The plant prefers to grow in places with low temperature and occurs in regions having high altitude with low rainfall or low altitude with high rainfall either in form of pure or mixed forests. ${ }^{2}$ The plant may form a pioneer species in glacial forelands or may also form the primary species in old growth mixed forests along with Cedrus deodara, Picea smithiana, Abies pindrow in temperate region or may be associated with Betula utilis and Juniperus macropoda in altitudes beyond 3000 meters near the tree line. ${ }^{3}$ The plant prefers to grow on deep moist soils but may also adapt itself well on fertile, well drained sandy clay to sandy clay loamy soil. ${ }^{4}$

Pinus wallichiana is used mainly for timber and stands next to deodar in commercial importance. The sap wood is whitish while the heartwood is light pink to red having dark striations, resinous, straight, even grained with medium fine texture, soft and moderately heavy. The wood acts as a good source of fuel and yields good quality charcoal having calorific value of 4995 . The timber is extensively used in making internal fittings of houses, planks, window frames and furniture. ${ }^{5}$ In addition to timber, the plant is also exploited for extracting oleoresins which is used for the production of turpentine oil, needle oil and camphor. ${ }^{6}$ The plant also finds immense medicinal value among different ethnic communities living in Himalayan region. The resin obtained from the plant is used for wounds and burnt wood called 'Kaalo' is used as antiseptic.? The resin is mixed with honey and is used for wound healing, antiseptic, gonorrhea, abscess, ulcer and burning sensation. ${ }^{8}$ The fruits and latex of the plants are also applied topically for treating cuts and wounds. ${ }^{9}$ The resin also finds application in curing chaffing of heels ${ }^{10}$ and is also used with onion paste for treating wounds and cuts. ${ }^{11}$

Thus based on the extensive ethnic usage pattern of the plant, an attempt has been made to summarize the various ethnomedicinal and ethnobotanical uses of Pinus wallichiana across various Himalayan regions. In addition to it, a detailed enlisting of various chemical constituents and biological activities of various plant parts have also been summarized in this paper with google scholar and pubmed forming the platform of literature search.

\section{Morphology of the plant}

Pinus wallichiana attains a height of more than 50 meters having a straight trunk and short down curved branches which are longer in solitary trees thereby creating a dome like structure (Figure 1A). ${ }^{12}$ The trunk is covered by bark which is smooth and resinous when young turning grey and corky with shallow fissures at maturity (Figure 1B). ${ }^{12}$ Leaves or needles are bluish green in colour occurring in cluster of five per fascicle and are $10 \mathrm{~cm}$ to $20 \mathrm{~cm}$ in 
length. Female cones are light brown at maturity and highly resinous. Female cones occur in groups of 1 to $6,20 \mathrm{~cm}$ to $30 \mathrm{~cm}$ long. The cone is erect, bluish green when young and becomes pendant, light brown at maturity. The apophysis is pale brown in colour $^{13}$ (Figures $\left.1 \mathrm{C} \& 1 \mathrm{E}\right) .^{12}$ The male cones are ovoid or globose, short lived, comprising of scales or microsporophylls each bearing a pair of pollen sacs on the lower surface. The male cones are $8-10 \times 3 \mathrm{~mm}$ in dimension. Seeds are ovoid, 6-10 X 5-6 mm in dimension having membranous wings of 1.5 to $3 \mathrm{~cm}$ in dimension. ${ }^{14,12}$

\section{TAXONOMIC CLASSIFICATION}

Subclass: Pinidae

Order: Pinales

Family: Pinaceae

Genus: Pinus

Species: wallichiana ${ }^{15}$

\section{TRADITIONAL USE}

Pinus wallichiana is deeply assembled within the culture and tradition of the people living in Himalayan and adjoining areas. The used by indigenous people for a variety of purpose which may be grossly divided into non-medicinal and medicinal uses. Non-medicinal uses include the use of plants for thatching and roofing, shelter, fuel wood, construction and infrastructural items and furniture. Medicinal uses include use of various parts of plant or resin for curing of various ailments such as healing, fever, bacterial diseases etc. The detailed nonmedicinal and medicinal use of Pinus wallichiana by ethnic people residing in various regions of Himalaya and adjoining mountains are tabulated in Tables 1 and 2.

\section{CHEMICAL CONSTITUENT}

Chemical constituents of various plant parts of Pinus wallichiana have been worked out in details by various groups of researchers using different solvents and techniques for extraction and detection. It was observed that the essential oils from the needle and turpentine contains terpenes as the major constituent. The alcoholic extract of various parts of plant contains a wide array of compound namely hydrocarbons, terpene acids, organic acids, flavonoids, flavonoid glycosides, terpene alcohols etc. The detailed chemical constituent of various plant parts of Pinus wallichiana is tabulated in Table 3 and structure of selected chemical constituent is depicted in Figure 1.

\section{ANTIOXIDANT ACTIVITY}

The antioxidant activity of the plant is also studied by various groups of researchers. It has been reported in one study that the crude methanolic extract of leaves and fruits of Pinus wallichiana showed strong antioxidant activity when tested with ferric thiocyanate and thiobarbituric acid methods. The results from their study indicated that the leaves possess a free radical scavenging potential and a protective effect towards lipid peroxidation. The activity of the extract was greater

Table 1: Non-medicinal use of Pinus wallichiana A.B. Jacks.

\begin{tabular}{|c|c|c|c|c|}
\hline S.No. & Region & $\begin{array}{l}\text { Vernacular } \\
\text { name }\end{array}$ & Plant part and their uses & References \\
\hline 1. & $\begin{array}{l}\text { Bandipore District, Jammu and } \\
\text { Kashmir, India }\end{array}$ & Chi & Seeds are eaten raw by children. & 16 \\
\hline 2. & $\begin{array}{l}\text { District Kinnaur, Himachal } \\
\text { Pradesh, India }\end{array}$ & Chilam, Golda & The tree is used as fuel, timber and for making tools. & 17 \\
\hline 3. & $\begin{array}{l}\text { Shimla Hills, Himachal Pradesh, } \\
\text { India }\end{array}$ & Kail & The wood is used for timber. It yields excellent charcoal. & 18 \\
\hline 4. & $\begin{array}{l}\text { Kashmir Valley, Jammu and } \\
\text { Kashmir, India }\end{array}$ & $\begin{array}{l}\text { Kail, Kaeur, } \\
\quad \text { Kairo }\end{array}$ & $\begin{array}{l}\text { The timber is used for making buildings, furniture, bridges, viaducts, } \\
\text { railway sleepers, street paving blocks, carving, box boards, paper pulps } \\
\text { etc. The oleoresin yields turpentine which is the starting material for } \\
\text { production of light and heavy tar oil, turpentine pitch, pyroligneous acids } \\
\text { and charcoal as residue. }\end{array}$ & 19 \\
\hline 5. & Kupwara, Kashmir, India & Kayar & $\begin{array}{l}\text { The timber is used for making furniture, and houses. The wood and cones } \\
\text { are used as firewoods. Charcoal is obtained from cone, branches and } \\
\text { needles. }\end{array}$ & 20 \\
\hline 5. & Uttarakhand, India & Kail & The bark yields a black coloured dye. & 21 \\
\hline 6. & $\begin{array}{l}\text { Tones Valley, Garhwal Himalaya, } \\
\text { Uttarakhand, India }\end{array}$ & & The Plant is used for household construction. & 22 \\
\hline 7. & $\begin{array}{l}\text { Apatani Plateau, Arunachal } \\
\text { Pradesh }\end{array}$ & & $\begin{array}{l}\text { Used as Timber, fuel wood, handicrafts, housing and ritualistic material, } \\
\text { food. }\end{array}$ & 23 \\
\hline 8. & $\begin{array}{l}\text { Ayubia National Park and } \\
\text { Miandam Valley, Pakistani } \\
\text { Hindukush, Pakistan }\end{array}$ & Kail/ Peyoach & The stem is used for fuel and furniture. & 24 \\
\hline 9. & Malam Jabba, SWAT, Pakistan & Peoch & Plant is used as fuel wood and making of furniture. & 25 \\
\hline 10. & Malam Jabba Valley, Swat, Pakistan & Peoch & The plant is used as fuel wood, for making furniture. & 26 \\
\hline 11. & $\begin{array}{l}\text { Utror and Gabral Valleys, District } \\
\text { Swat, Pakistan }\end{array}$ & Peeuch & $\begin{array}{l}\text { The tree finds use in timber and furniture industry, match industry, } \\
\text { construction of bridges and as fuel wood. It finds use as decoration item. }\end{array}$ & 27 \\
\hline
\end{tabular}


Table 2: Ethnomedicinal use of Pinus wallichiana A.B. Jacks.

\begin{tabular}{|c|c|c|c|c|}
\hline S.No. & Region & $\begin{array}{l}\text { Vernacular } \\
\text { name }\end{array}$ & Plant part and their uses & References \\
\hline 1. & $\begin{array}{l}\text { Bangus Valley, Kashmir } \\
\text { Himalaya, India. }\end{array}$ & Kayur & $\begin{array}{c}\text { Resin, latex: Stems of plants produce latex called 'kangul' and is applied to heal cracks } \\
\text { on heels. }\end{array}$ & 46 \\
\hline 2. & Jammu and Kashmir, India. & Kayud & Needles: Needles are fed to the cattle for cure from abdominal worms. & 47 \\
\hline 3. & $\begin{array}{l}\text { Sophian forest area, Jammu and } \\
\text { kashmir, India. }\end{array}$ & Kayod & Used for the treatment of cut, wounds and fractures. & 48 \\
\hline 4. & $\begin{array}{l}\text { Sankaracharya Hills, Jammu and } \\
\text { Kashmir, India. }\end{array}$ & Kayiur, Yar & $\begin{array}{l}\text { Resin is used for the treatment of boils, cuts, cracked heels and wounds. It also acts as } \\
\text { antiphlogistic and styptic. It is used for the treatment of influenza. }\end{array}$ & 49 \\
\hline 5. & $\begin{array}{l}\text { Kupwara, Jammu and Kashmir, } \\
\text { India. }\end{array}$ & Kayar & $\begin{array}{l}\text { Latex produced from the stem is commonly called Kangul and is applied to cure heel } \\
\text { cracks. It is also used to cure wounds and evacuation of pus. }\end{array}$ & 50 \\
\hline 6. & Kupwara, Kashmir, India & Kayar & The latex from stem called 'Kangul' is applied to heal cracked heels. & 51 \\
\hline 7. & $\begin{array}{l}\text { Sewa river catchment area, } \\
\text { District Kathua, Jammu and } \\
\text { Kashmir, India. }\end{array}$ & Kail & Oleoresin is applied for the treatment of cracked heels. & 52 \\
\hline 8. & $\begin{array}{l}\text { Kashmir Valley, Jammu and } \\
\text { Kashmir, India }\end{array}$ & $\begin{array}{l}\text { Kail, Kaeur, } \\
\text { Kairo }\end{array}$ & $\begin{array}{l}\text { The leaf oil is used for medicinal purposes. Leaves are weaved to prepare medicinal } \\
\text { under clothing. The dark brown viscous and sticky substances called 'killam' is } \\
\text { obtained from wood and is applied to arms and legs of farmers for protection against } \\
\text { insect bites while working in waterlogged paddy fields. }\end{array}$ & 19 \\
\hline 9. & $\begin{array}{l}\text { Khistwar, Jammu and Kashmir, } \\
\text { India }\end{array}$ & Chew & The resin from young saplings is used for the treatment of cuts and wounds in skin. & 53 \\
\hline 10. & $\begin{array}{c}\text { Pabbar Valley, Shimla, Himachal } \\
\text { Pradesh, India }\end{array}$ & Kail, Chilta & $\begin{array}{c}\text { Resins possess antiseptic properties and used to cure cuts, cracks in feet and wounds. } \\
\text { Youngs shoots are used as bandage for treatment of broken joints of humans and } \\
\text { cattle. }\end{array}$ & 54 \\
\hline 11. & $\begin{array}{l}\text { Manali Wildlife Sanctuary, } \\
\text { Himachal Pradesh, India }\end{array}$ & Kail & Used for the treatment of abscesses, dislocation of joints, ulcer and unconsciousness. & 55 \\
\hline
\end{tabular}

Table 3: Chemical constituent of various plant part of Pinus wallichiana A.B. Jacks.

\begin{tabular}{|c|c|c|}
\hline Plant Part & Chemical constituents & Reference \\
\hline $\begin{array}{l}\text { Needle } \\
\text { essential oil }\end{array}$ & $\begin{array}{l}\alpha \text {-Pinene }(25.2 \%), \beta \text { - Pinene (46.8\%), Myrcene }(9.5 \%), \alpha \text { - Terpineol }(2.3 \%) \text {, Caryophyllene Oxide }(2.1 \%) \text {, Trans } \\
\text { Caryophyllene (1.8\%), Limonene (1.0\%), } \alpha \text { - Cadinol }(0.9 \%) \text {, Camphene }(0.9 \%), \alpha \text { - Terpinyl Acetate }(0.8 \%) \text {, Delta- } \\
\text { 3-Carene }(0.8 \%), \alpha \text { - Bisabolol }(0.6 \%), \alpha \text { - Humulene }(0.5 \%), \alpha \text { - Phellandrene }(0.4 \%), \delta \text { - Cadinene }(0.4 \%) \text {, Trans- } \\
\text { pinocarveol }(0.4 \%) \text {, Geranyl acetate }(0.1 \%) \text {. }\end{array}$ & 74 \\
\hline $\begin{array}{l}\text { Needle } \\
\text { essential oil }\end{array}$ & $\begin{array}{l}\alpha \text { - Thujene }(0.1 \%) \text {, Tricyclene }(0.1 \%), \alpha \text {-Pinene }(14.8 \%), \alpha \text {-Fenchene }(0.3 \%) \text {, Camphene }(1.0 \%), \beta \text { - Pinene }(34.0 \%) \text {, } \\
\text { Myrcene }(1.3 \%), \alpha \text { - Phellandrene }(0.3 \%), \alpha \text { - Terpinene }(0.6 \%), \text {-Cymene }(0.1 \%), \text { Limonene }(17.8 \%), \alpha \text {-Pinene } \\
\text { oxide }(0.6 \%) \text {, Fenchone }(0.1 \%) \text {, cis-Limonene oxide }(0.3 \%) \text {, trans-Pinocarveol }(2.1 \%) \text {, cis-Pinene hydrate }(0.3 \%) \text {, } \\
\text { trans-Vertbenol }(0.5 \%) \text {, Pinocarvone }(1.3 \%) \text {, cis-Pinocamphone }(0.4 \%) \text {, Terpinen- } 4 \text {-ol }(0.2 \%), \alpha \text {-Terpineol }(0.3 \%) \text {, } \\
\text { Myrtenal }(2.1 \%), \text { Myrtenol }(2.1 \%) \text {, Verbenone }(0.3 \%) \text {, trans-Carveol }(0.7 \%) \text {, Carvone }(0.5 \%) \text {, Undecanone }(0.7 \%) \text {, trans- } \\
\text { Pinocarvylacetate }(0.9 \%) \text {, cis-Pinocarvylacetate }(1.9 \%) \text {. }\end{array}$ & 75 \\
\hline $\begin{array}{l}\text { Methanolic } \\
\text { extract of } \\
\text { needle }\end{array}$ & 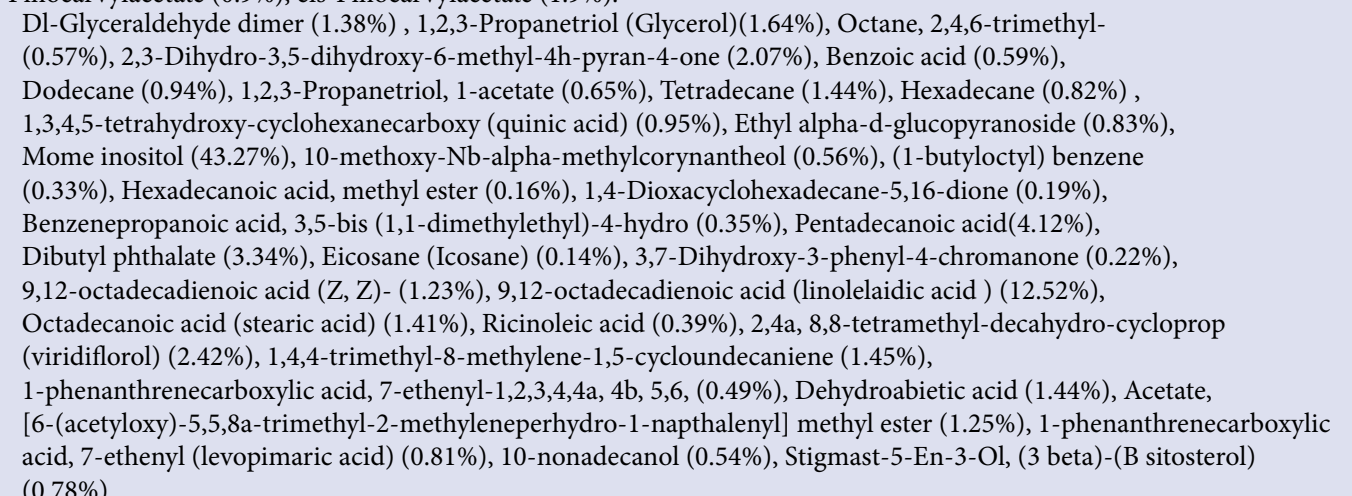 & 76 \\
\hline $\begin{array}{l}\text { n-hexane } \\
\text { fraction of } \\
\text { aqueous } \\
\text { methanolic } \\
\text { extract of } \\
\text { needle }\end{array}$ & $\begin{array}{l}\beta \text {-Sitosterol, } \beta \text {-Sitosterol 3-O- } \beta \text {-D-glucopyranoside, 5-Hydroxy-7-methoxy-2-(4-methoxy phenyl)-4H-chromen-4- } \\
\text { one, Oleanolic acid. }\end{array}$ & 77 \\
\hline
\end{tabular}




\begin{tabular}{|c|c|c|}
\hline Plant Part & Chemical constituents & \\
\hline $\begin{array}{l}\text { Methanolic } \\
\text { extract of } \\
\text { needle }\end{array}$ & Isorhamnetin (2.857\%), Quercetin (21.426\%). & 78 \\
\hline $\begin{array}{l}\text { Diethyl ether } \\
\text { extract of } \\
\text { needle }\end{array}$ & Isorhamnetin (2.857\%), Quercetin (5.712\%). & 78 \\
\hline Turpentine & $\begin{array}{l}\alpha \text { - Pinene ( } 90.7 \%) \text {, Camphene }(2.5 \%), \beta \text { - Pinene/Sabinene/C11 }(2.1 \%), \Delta \text {-3-Carene/myrcene }(0.4 \%), \alpha \text { - Terpinene }(0.1 \%) \text {, Limonene } \\
(0.5 \%), \beta \text { - Phellandrene }(0.1 \%), \gamma \text { - Terpinene (Trace), p-Cymene }(0.2 \%) \text {, Terpinolene }(0.4 \%) \text {, Longipinene }(0.3 \%) \text {, Cyclosativene } \\
\text { (Trace), Longicyclene (Trace), Sativene (Trace), Longifolene }(0.6 \%), \beta \text { - Caryophyllene/ terpinen- } 4 \text {-ol }(0.5 \%) \text {, Trans- } \beta \text {-Farnesene/ } \alpha \text { - } \\
\text { humulene }(0.1 \%), \alpha \text { - Terpineol/borneol }(0.2 \%) \text {. }\end{array}$ & 79 \\
\hline Resein Acid & $\begin{array}{l}\text { Pimaric Acid (0.7\%), Levopimaric Acid/Palustric Acid (9.7\%), Isopimaric Acid (23.2\%), Lambertianic Acid (20.5\%), Dehydroabietic } \\
\text { Acid (1.7\%), Abietic Acid (31.5\%), Neoabietic Acid (4.8\%). }\end{array}$ & 79 \\
\hline $\begin{array}{l}\text { Lipophillic } \\
\text { constituents of } \\
\text { dry bark }\end{array}$ & 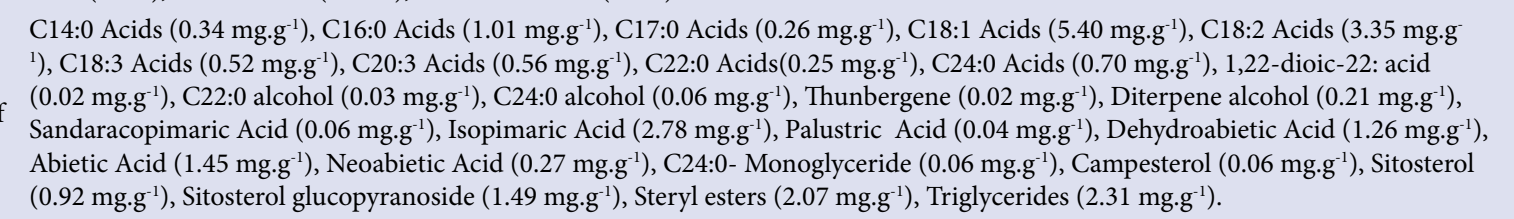 & 80 \\
\hline $\begin{array}{l}\text { Hydrophillic } \\
\text { constituent of } \\
\text { dry bark }\end{array}$ & $\begin{array}{l}\text { Sugars and sugar alcohols }\left(70.0 \mathrm{mg} \cdot \mathrm{g}^{-1}\right), 3,4 \text {-Dihydroxybenzoic Acid }\left(0.66 \mathrm{mg} \cdot \mathrm{g}^{-1}\right) \text {, Ferulates }\left(4.78 \mathrm{mg} \cdot \mathrm{g}^{-1}\right) \text {, Secoisolariresinol }(0.14 \\
\left.\text { mg. } \mathrm{g}^{-1}\right) \text {, Monomethyl Pinosylvin }\left(0.48 \mathrm{mg} \cdot \mathrm{g}^{-1}\right) \text {, Dihydro-monomethyl pinosylvin }\left(0.04 \mathrm{mg} \cdot \mathrm{g}^{-1}\right) \text {, Resveratrol glycoside }\left(9.09 \mathrm{mg} \cdot \mathrm{g}^{-1}\right) \text {, } \\
\text { Catechin }\left(5.78 \mathrm{mg} \cdot \mathrm{g}^{-1}\right) \text {, Taxifolin derivative }\left(2.11 \mathrm{mg} \cdot \mathrm{g}^{-1}\right) \text {, Catechin and gallocatechin derivatives }\left(11.0 \mathrm{mg} \cdot \mathrm{g}^{-1}\right) \text {. }\end{array}$ & 80 \\
\hline $\begin{array}{l}\text { Methanol } \\
\text { extract of bark }\end{array}$ & Kaempferol (2.30\%), Rhamnetin (2.08\%), Isorhamnetin (2.005\%), Quercetin (5.009\%), Myricetin (3.0\%). & 78 \\
\hline $\begin{array}{l}\text { Diethyl ether } \\
\text { extract of bark }\end{array}$ & Rhamnetin (2.08\%), Isorhamnetin (1.847\%). & 78 \\
\hline $\begin{array}{l}\text { Ethyl acetate } \\
\text { extract of bark }\end{array}$ & Kampherol (1.857\%), Quercetin (5.001\%). & 78 \\
\hline
\end{tabular}

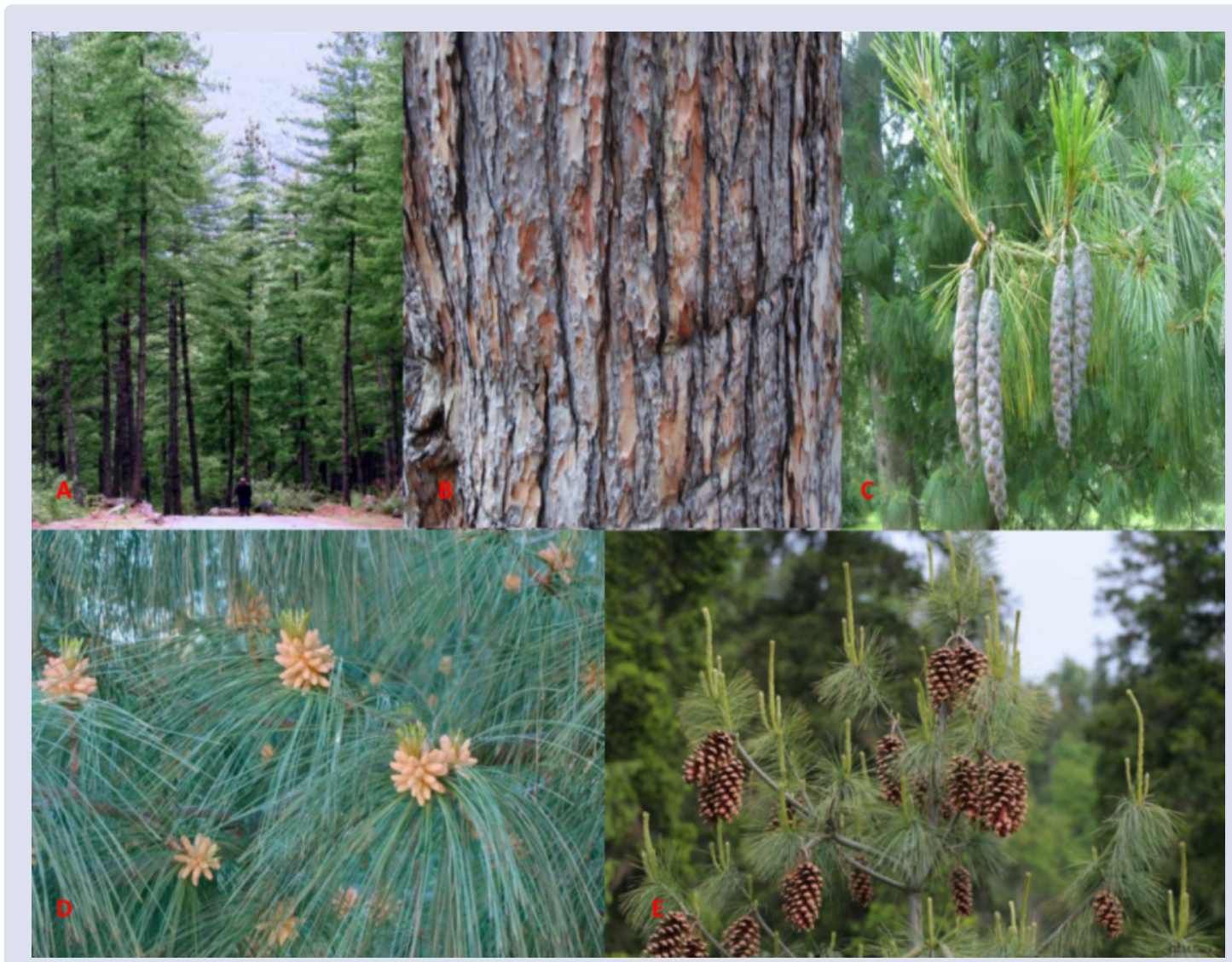

Figure 1: Pinus wallichiana A.B. Jacks: (A) Full grown trees in natural habitat, (B) Barks, (C) Unripe female cones, (D) Male Cones with vegetative leaves, (E) Ripe female cones with vegetative leaves. ${ }^{12}$ 
than Vitamin E and comparable to butylated hydroxy toluene taken as positive control. ${ }^{82}$ It was further observed that hydromethanolic extract and aqueous extract of the leaves showed free radical scavenging and nitric oxide scavenging activity. The hydrogen peroxide scavenging activities of the extracts were more than that of standard antioxidant ascorbic acid. ${ }^{83}$ The essential oil of Pinus wallichiana exhibited free radical scavenging activity as evident from DPPH scavenging assays. ${ }^{74}$

\section{ANTIMICROBIAL ACTIVITY}

Pinus wallichiana exhibits antimicrobial properties. It was observed that $\mathrm{n}$-hexane fraction of ethanolic extract of needle inhibited the growth of fungus Microsporium cannis with minimum inhibitory concentration of $25 \mu \mathrm{g} \cdot \mathrm{ml}^{-1}$. In addition to it, the ethyl acetate fraction brought mortality of Tribolium castaneum, Rhyzopertha dominica and Callosobruchus analis exhibiting a mortality range of (20-40) at a crude extract concentration of $20 \mathrm{mg}$ per $2 \mathrm{ml}$ of acetone. ${ }^{84}$ The needle essential oil also showed inhibitory activity against Fusarium verticillioides with minimum inhibitory concentration of 40 ppm exhibiting 25\% or less growth than that of the control. ${ }^{75}$ It was also reported that the hydromethanolic extract of the needles at concentration of $47.8 \mathrm{mg} \cdot \mathrm{ml}^{-1}$ showed highest inhibitory activity against Pseudomonas aeruginosa and Escherichia coli with a zone of inhibition of $15.66 \pm 1.1 \mathrm{~mm}$ and $14 \pm 0.57 \mathrm{~mm}$ respectively. ${ }^{83}$ Additionally, the methanolic extract of the needles of the plant showed bactericidal activity against Bacillus subtilis, Agrobacterium tumefaciens, Xanthmonas phaseoli, Erwinia chrysanthemi and Escherichia coli with activities ranging $54 \%$ and $81 \%{ }^{85}$ The antimicrobial activity of the plant is tabulated in Table 4.

\section{ANTIPROLIFERATIVE ACTIVITY}

The essential oil of Pinus wallichiana exhibited a dose dependent antiproliferative activity against THP-1 (Leukemia), A-549 (Lung), HEP-2 (Liver), IGR-OV-1 (Ovary), PC-3 (Prostate) cell lines. The maximum anti-proliferative activity was obtained when the cell lines were treated with $100 \mu \mathrm{g} \cdot \mathrm{mL}^{-1}$ of oil with IC50 values of $5.6 \pm 1.4,6.1 \pm$ $0.8,9.0 \pm 1.5,9.9 \pm 1.9,6.9 \pm 1.2$ respectively. These values were less than those of standard drugs Paclitaxel and Mitomycin-C taken as positive control. $^{74}$

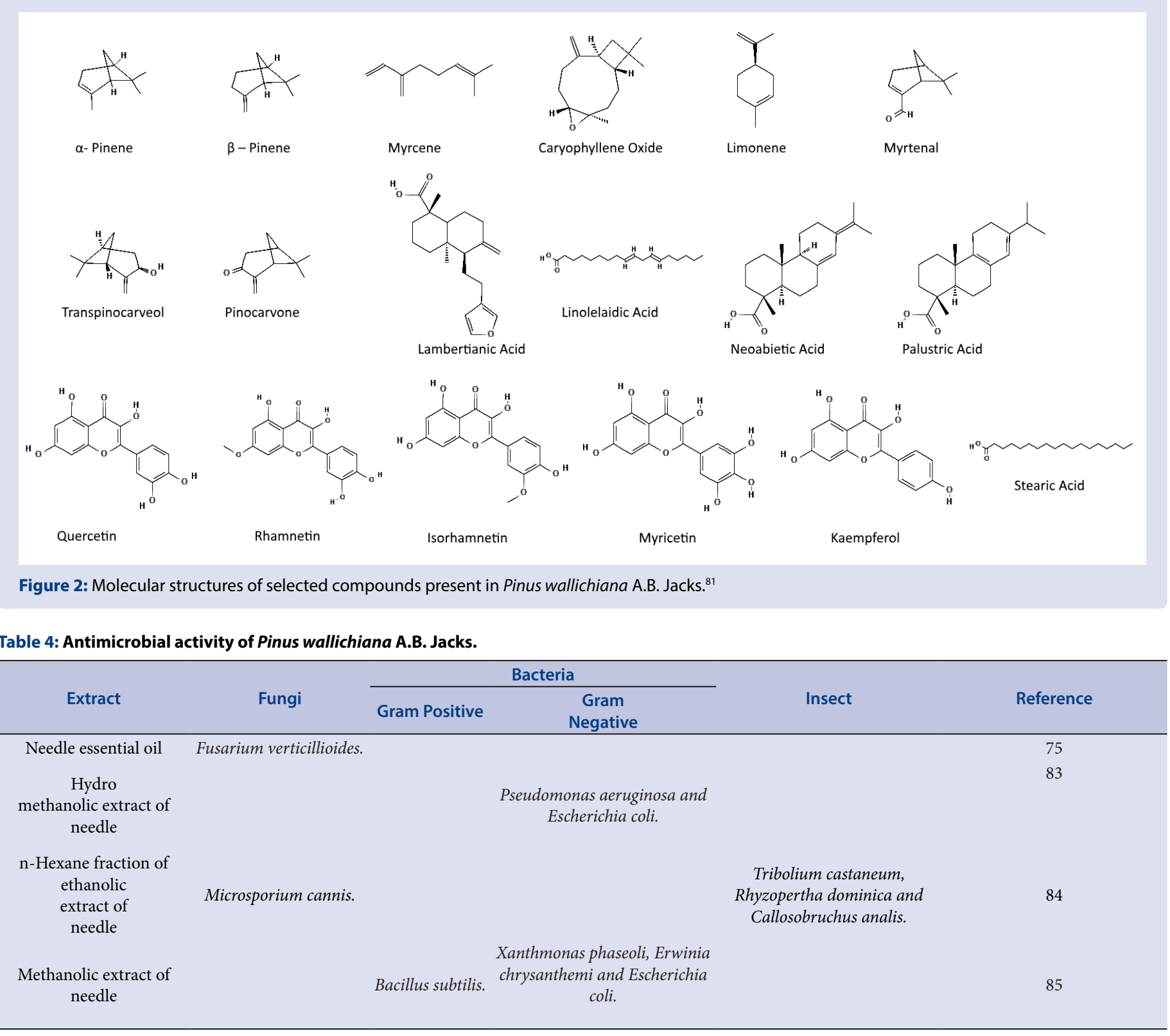




\section{CONCLUSION}

The Himalayan mountain is one of the prominent biodiversity hotspot of the world and boasts of a numerous plants which are of direct use to the local people. The plants growing in the region play a major role in the life of the people living in the Himalayan region and are intricately assembled in their culture and tradition. This has lead to emergence of traditional remedies as an important aspect of their livelihood. It plays a major role in overall health care of the people living in far flung regions of the mountains where conventional health care facility are limiting. This paper projects detailed usage pattern of Pinus wallichiana growing in different sectors himalayan region. The plant is extensively used in both non medicinal and medicinal purposes. Though all parts aerial parts of the plants are utilised by the people for a variety of purposes, it is noted that in most cases resins and latex are exploited for cure of variety of ailments by local people. Investigations on the chemical constituents of various plant parts reveal the presence of various terpenoids and flavonoids most of which act as strong antioxidants. Additionally, the antioxidant, free radical scavenging activity and inhibition of lipid peroxidation of the plant have also been investigated by different groups of researchers with a positive outcome from their findings. Further the plant showed inhibitory activity towards fungi, bacteria and insects indicating its antimicrobial potential. The anticancer activity of the plant has also been established by its Antiproliferative activity.

To summarize, the popularity of the plant among local people of Himalayan region as herbal remedy may be due to the presence of terpenoids and flavonoids whose fundamental role is modulation of oxidative balance of the living system and inhibition of microbial activity. Though the plant is widely used by local people proper scientific investigation of its medicinal property is scarce. Thus, investigation of pharmacological activity based on the traditional usage pattern and development of drug through clinical trials would be an effective way of bio prospecting the plant for medicinal use. As the plant is plenty in the Himalayan region, it can act as a cheap source of raw material for development of drugs for efficient management of free radical induced diseases in and around Indian subcontinent.

\section{REFERENCES}

1. Ghimire B, Mainali KP, Lekhak HD, Chaudhary RP, Ghimeray AK. Regeneration of Pinus wallichiana $A B$ Jackson in a trans-himalayan dry valley of north-central Nepal. Himalayan Journal of Sciences. 2010;6(8):19-26.

2. Rahman IU, Khan N, Ali K. Variability assessment of some morphological traits among blue pine (Pinus wallichiana) communities in Hindukush ranges of SWAT, Pakistan. Pak J Bot. 2017;49(4):1351-7.

3. Shah SK, Bhattacharyya A, Chaudhary V. Climatic influence on radial growth of Pinus wallichiana in Ziro valley, Northeast Himalaya. Curr Sci. 2009;96(5):697702.

4. Rahman IU, Khan N, Ali K, Ahmad S. Vegetation-environment relationship in Pinus wallichiana forests of Swat Hindukush Range of Pakistan. J For Res. 2018;1-11.

5. Bhat GM, Mughal AH, Malik AR, Khan PA, Shazmeen Q. Natural regeneration status of blue pine (Pinus wallichiana) in north west Himalayas, India. The Ecoscan. 2015;9(3\&4):1023-6.

6. Aslam M, Reshi ZA, Siddiqui TO. Genetic divergence in half sib progenies of Pinus wallichiana A.B. Jackson pus trees in Kashmir Himalaya, India. Trop Ecol. 2011;52(2):201-8

7. Khan SW, Khatoon S. Ethnobotanical studies of useful trees and shrubs of Harmosh and Bugrote Valleys in Gilgit, Northern areas of Pakistan. Pak J Bot. 2007;39(3):699-710.

8. Alamgeer, Sharif A, Asif H, Younis W, Riaz H, Bukhari IA, Assiri AM. Indegenous medicinal plants of Pakistan used to treat skin disease. Chin Med. 2018;13:52:126.

9. Nand K, Naithani S. Ethnobotanical uses of wild medicinal plants by local communities in the Asi Ganga sub basin, Western Himalaya. J Complement Med Res. 2018;9(1):34-46.

10. Hassan A, Hassan S, Nasir MA. An ethnobotanical study of medicinal plants used by local people of Neel valley, Ramban, Jammu and Kashmir, India. SSRG International Journal of Agriculture \& Environmental Science. 2018;5(3):17-20.
11. Balodi KN, Purohit MV, Sridhar V, Arunachalam K. Ethno-medicinal uses of various plants species among the Jaad and Bhotiya community of Uttarakhand, Western Himalaya. Ethno Med. 2018;12(3):189-97.

12. American Conifer Society. Available from: http://conifersociety.org/conifers/ conifer/pinus/wallichiana/

13. Sharma A, Sharma L, Goyal R. A review of Himalayan pine species: Ethnopharmacological, phytochemical and pharmacological aspcects. Pharmacogn J. 2018;10(4):611-9.

14. Bhutan biodiversity portal. Available from: https://biodiversity.bt/species/ show/2243.

15. Christenhusz MJM, Reveal JL, Farjon A, Gardner MF, Mill RR, Chase MW. A new classification and linear sequence of extant gymnosperms. Phytotaxa. 2011;19:55-70.

16. Singh B, Sultan P, Hassan QP, Gairola S, Bedi YS. Ethnobotany, traditional knowledge, and diversity of wild edible plants and fungi: A case study in the bandipora district of kashmir himalaya, India. J Herbs Spices Med Plants. 2016;22(3):247-78.

17. Lal C, Prasher RS. Traditional knowledge systems and conservation practices in tribal society of Western Himalayas: A case study of district Kinnaur of Himachal Pradesh. International Journal of Farm Sciences. 2016;6(3):159-71.

18. Singh KJ, Thakur AK. Medicinal plants of the Shimla hills, Himachal Pradesh: A Survey. Int J Herbal Med. 2014;2(2):118-27.

19. Dar AR, Dar GH. The wealth of Kashmir Himalaya - Gymnosperms. Asian J Plant Sci. 2006;5(2):251-9.

20. Lone FA, Lone S, Aziz MA, Malla FA. Ethnobotanical studies in the tribal areas of district Kupwara, Kashmir, India. Int J Pharm Bio Sci. 2012;3(4):B:399-411.

21. Gaur RD. Traditional dye yielding plants of Uttarakhand, India. Nat Prod Rad. 2008;7(2):154-65.

22. Rawat VS, Rawat YS, Shah S. Indigenous knowledge and sustainable development in the Tones valley of Garhwal Himalaya. J Med Plants Res. 2010;4(19):2043-7.

23. Chaudhary P, Dollo M, Bagra K, Yakang B. Traditional biodiversity conservation and natural resource management system of some tribes of Arunachal Pradesh. Interdisciplinary Environmental Review. 2011;12(4):338-48.

24. Adnan M, Begum S, Khan AL, Tareen AM, Lee IJ. Medicinal plants and their uses in selected temperate zones of Pakistani Hindukush-Himalaya. J M Plant Res. 2012;6(24):4113-27.

25. Sher H, Al-Yemeni M. Economically and ecologically important plant communities in high altitude coniferous forest of Malam Jabba, Swat, Pakistan. Saudi J Biol Sci. 2011;18:53-61.

26. Ali H, Sannai J, Sher H, Rashid A. Ethnobotanical profile of some plant resources in Malam Jabba valley of Swat, Pakistan.2011. J Med Plant Res. 2011;5(18):4676-87.

27. Hamayun M, Khan SA, Iqbal I, Rehman G, Hayat T, Khan MA. Ethnobotanical profile of Utror and Gabral Valleys, District Swat, Pakistan. Ethnobotanical Leafets. 2005;1:9.

28. Khan N, Ahmed M, Ahmed A, Shaukat SS, Wahab M, Ajaib M, et al. Important medicinal plants of Chitral Gol National Park (CGNP), Pakistan. Pak J Bot. 2011;43(2):797-809.

29. Jan G, Jan FG, Hamayun M, Khan K, Khan A. Diversity and conservation status of vascular plants of Dir Kohistan valley, Khyber Pakhtunkhwa Province. J Bio \& Env Sci. 2014;5(1):164-72.

30. Awan MR, lqbal Z, Shah MS, Jamal Z, Jan G, Afzal M, et al. Studies on traditional knowledge of economically important plants of Kaghan Valley, Mansehra District, Pakistan. J Med Plants Res. 2011;5(16):3958-67.

31. Jan S, Khan MA, Siraj ud din, Murad M, Hussain M, Ghani A. Herbal remedies used for gastrointestinal disorders in Kaghan valley, NWFP, Pakistan. Pak J Weed Sci Res. 2008;14(3-4):169-200.

32. Khan A, Gilani SS, Hussain F, Durrani MJ. Ethnobotany of Gokand Valley, District Buner, Pakistan. Pak J Biol Sci. 2003;69(4):363-9.

33. Haq F, Ahmad H, Ullah R, lqbal Z. Species diversity and ethno botanical classes of the flora of allai valley district battagram Pakistan. International Journal of Plant Research. 2012;2(4):111-23.

34. Sher Z, Hussain F, Ibrar M. Traditional knowledge on plant resources of Ashezai and Salarzai Valleys, District Buner, Pakistan. Afr J Plant Sci. 2014;8(1):42-53.

35. Jabeen A, Khan MA, Ahmad M, Zafar M, Ahmad F. Indigenous uses of economically important flora of Marghallah Hills National Park, Islamabad, Pakistan. Afr J Biotechnol. 2009;8(5):763-84.

36. Ahmed E, Arshad M, Saboor A, Qureshi R, Mustafa G, Sadiq S, Chaudhari SK. Ethnobotanical appraisal and medicinal use of plants in Patriata, New Murree, evidence from Pakistan. J Ethnobiol Ethnomed. 2013;9(13):1-10.

37. Ibrar M, Hussain F, Sultan A. Ethnobotanical studies of plant resources of Ranyal hills, district Shangla, Pakistan. Pak J Bot. 2007;39(2):329-37.

38. Shah GM, Khan MA, Hussain M, Jamal Z. An ethnobotanical note on fuel wood and timber plant species of Siran Valley, Pakistan. Journal of Biological Sciences. 2007;7(2):349-53 
39. Daud M, Wazir SM, Khan RU, Khan SU, Khan A, Ullah I, Khattak A. Ethnotaxonomical study of gymnosperms of Razmak North Waziristan Agency (NWA). Can J App Sci. 2013;3(3):459-72.

40. Wangchuk S, Siebert S, Belsky J. Fuelwood use and availability in Bhutan: Implications for national policy and local forest management. Hum Ecol. 2014;42(1):127-35

41. Bhattarai S, Chaudhary RP, Taylor RSL. Plants used as fence and fuelwood in Manang district, Central Nepal. Scientific World. 2007;5(5):107-11.

42. Manandhar NP. Plants used for incense in Nepal. Indian J Tradit Know. 2004;3(1):101-4.

43. Joshi AR, Joshi K. Ethnobotanical study of Bagmati and Langtang watershed, Nepal: Raw materials of plant origin and their indigenous uses. Journal of nontimber forest products. 2005;12(2):76-82.

44. Joshi AR, Joshi K. Plant diversity and Ethnobotanical notes on tree species of Syabru Village, Langtang National Park, Nepal. Ethnobotanical Leaflets. 209;13:651-64.

45. Sidgel SR, Rokaya MB, Timsina B. Plant inventory and ethnobotanical study of Khimti Hydropower project, Central Nepal. Scientific World. 2013;11(11):105-12.

46. Ishtiyak P, Hussain SA. Traditional use of medicinal plants among tribal communities of Bangus valley, Kashmir Himalaya, India. Ethno Med. 2017;11(4):318-31.

47. Ahmad S, Ratodra S, Singh JP, Verma DK, Multan SM. Ethnoveterinary uses of some important plants by pastoralists in Kashmir Himalaya. SKUAST Journal of Research. 2007;19(1):121-8.

48. Jan RA, Khare N. Ethnopharmacological uses of plants among tribal and rural folks of sophian forest area of kashmir. International Journal of Science and Research. 2015;4(5):232-4.

49. Kumar K, Sharma YP, Manhas RK, Bhatia H. Ethnomedicinal plants of Shankacharya hill, Srinagar, J\& K, India. J Ethnopharmacol. 2015;170.225-74.

50. Mir MY. Indigenous knowledge of using medicinal plants in treating skin disease by tribal's of Kupwara, J\& K, India. Int J Herb Med. 2014;1(6):62-8.

51. Lone FA, Lone S, Aziz MA, Malla FA. Ethnobotanical studies in the tribal areas of district Kupwara, Kashmir, India. Int J Pharm Bio Sci. 2012;3(4):B:399-411.

52. Khan M, Kumar S, Hamal IA. Medicinal plants of sewa river catchment area in northwest Himalaya and its implication for conservation. Ethnobotanical Leaflets. 2009;13:1113-39.

53. Kumar M, Paul Y, Anand VK. An ethnobotanical study of medicinal plants used by the locals in Kishtwar, Jammu and Kashmir, India. Ethnobotanical Leaflets. 2009;13:1240-56

54. Chauhan PP, Nigam A, Santvan VK. Ethnobotanical survey of tree of Pabbar valley, Distt Shimla, Himachal Pradesh. Life Sci Leafl. 2014;53.24-39.

55. Rana MS, Samant SS. Diversity, indigenous uses and conservation status of medicinal plants in Manali wildlife sanctuary, North Western Himalaya. Indian J Tradit Know. 2011;10(3):439-59.

56. Samant SS, Pant S, Singh M, Lal M, Singh A, Sharma A, et al. Medicinal plants in Himachal Pradesh, North Western Himalaya, India. International Journal of Biodiversity Science \& Management. 2007;3(4):234-51.

57. Sharma P, Samant SS. Diversity, distribution and indigenous uses of medicinal plants of Parbati Valley of Kullu district in Himachal Pradesh, Northwestern Himalaya. Asian J of Adv Basic Sci. 2014;2(1):77-98.

58. Singh A, Lal M, Samant SS. Diversity, indigenous uses and conservation prioritization of medicinal plants in Lahaul valley, proposed Cold Desert Biosphere Reserve, India. International Journal of Biodiversity Science \& Management. 2009;5(3):132-54

59. Pala NA, Negi AK, Todaria NP. Traditional uses of medicinal plants of Pauri Garhwal, Uttarakhand. Nature and Science. 2010;8(6):57-61.

60. Phondani PC, Maikhuri RK, Rawat LS, Farooquee NA, Kala CP, Visvakarma SCR, et al. Ethnobotanical uses of plants among the bhotiya tribal communities of Niti Valley of Central Himalaya, India. Ethnobotany Research \& Applications. 2010;8:233-44

61. Negi VS, Maikhuri RK, Phondani PC, Rawat LS. An inventory of indigenous knowledge and cultivation practices of medicinal plants in Govind Pashu Vihar Wildlife Sanctuary, Central Himalaya, India. International Journal of Biodiversity, Science, Ecosystem Services \& Management. 2010;6(3-4):96-105.

62. Rahman IU, ljaz F, Afzal A, Iqbal Z, Ali N, Khan SM. Contributions to the phytotherapies of digestive disorders: Traditional knowledge and cultural drivers of Manoor Valley, Northern Pakistan. J Ethnopharmacol. 192:30-52.
63. Kayani S, Ahmad M, Sultana S, Khan SZ, Zafar M, Yaseen G, et al. Ethnobotany of medicinal plants among communities of alpine and sub alpine regions of Pakistan. Journal of Ethnopharmacology. 2015;164:186-202.

64. Ishtiaq ch M, Khan MA. An ethnomedicinal inventory of plants used for family planning and sex diseases in Samahni Valley, Pakistan. Indian J Tradit Know. 2008;7(2):277-83.

65. Khan SM, Page S, Ahmad H, Saheen H, Ullah Z, Ahmad M, et al. Medicinal flora and ethnoecological knowledge in the Naran Valley, Western Himalaya, Pakistan. J Ethnobiol Ethnomed. 2013;9(4).

66. Ziauddin, Jan S. Profile of medicinal plant resources in Maksini valley, Distt Dir (Lower) Khyber Pakhtunkhwa, Pakistan. International Journal of Biosciences. 2018;12(2):291-8

67. Ummara U, Bokhari TZ, Altaf A, Younis U, Dasti AA. Pharmacological study of Shogran valley flora, Pakistan. International Journal of Scientific \& Engineering Research. 2013;4(9):1419-27.

68. Khan RU, Wazir SM, Khan SU, Ullah R. Methods for the preparation of recipes and its uses for curing different diseases reported from district Bannu. Can J App Sci. 2014;4(2):51-65.

69. Sher H, Alyemeni MN, Wijaya L, Shah AJ. Ethnopharmaceutically important medicinal plants and its utilization in traditional system of medicine, observation from the Northern Parts of Pakistan. J Med Plants Res. 2010;4(18):1853-64.

70. Daud M, Wazir SM, Khan RU, Khan SU, Khan A, Ullah I, et al. Ethnotaxonomical study of gymnosperms of Razmak North Waziristan Agency (NWA). Can J App Sci. 2013;3(3):459-72.

71. Rokaya MB, Munzbergova Z, Timsina B. Ethnobotanical study of medicinal plants from the Humla district of Western Nepal. J Ethnopharmacol. 2010;130(3):485-504.

72. Kunwar RM, Adhikari N. Ethnomedicine of Dolpa district, Nepal: the plants, their vernacular names and uses. Lyonia. 2005;8(1):43-9.

73. Joshi AR, Joshi K. Ethnomedicinal plants used against skin diseases in some villages of kali gandaki, bagmati and tadi likhu watersheds of Nepal. Ethnobotanical Leaflets. 2007;11:235-46.

74. Yousuf Dar M, Shah WA, Mubashir S, Rather MA. Chromatographic analysis, anti-proliferative and radical scavenging activity of Pinus wallichiana essential oil growing in high altitude area of Kashmir, India. Phytomedicine. 2012;19:122833.

75. Dambolena JS, Gallucci MN, Luna A, Gonzalez SB, Guerra PE, Zunino MP. Composition, antifungal and antifumonisin activity of Pinus wallichiana, Pinus monticola and Pinus strobus essential oils from patagonia argentina. Journal of Essential Oil Bearing Plants. 2016;9(7):1769-75.

76. Joshi S, Rai N, Kumar N. Gas chromatography-mass spectroscopy analysis of phyotchemical constituents of methanolic extracts of needles of Pinus wallichiana. Asian J Pharm Clin Res. 2016;9(2):55-7.

77. Rahman TU, Uddin G, Liaqat W, Zaman K, Mohammad G, Choudhary MI. Phytochemical investigations of leaves of Pinus wallichiana. International Journal of Scientific Research and Essays. 2013;1(1):1-3.

78. Naeem I, Taskeen A, Mubeen H, Maimoona A. Characterization of flavonols present in barks and needles of Pinus wallichiana and Pinus roxburghii. Asian $J$ Chem. 2010;22(1):41-4

79. Coppen JWJ, Robinson JM, Kaushal AN. Composition of xylem resin from Pinus wallichiana and Pinus roxburghii. Phytochemistry. 1988;27(9):2873-5.

80. Wilfor S, Ali M, Karonen M, Reunanen M, Arfan M, Harlamow R. Extractives in bark of different conifer species growing in Pakistan. Holzforschung 2008;63:551-8.

81. Pubchem. Available from: https://pubchem.ncbi.nlm.nih.gov/

82. Emami SA, Sahani A, Khayyat MH. Antioxidant activity of leaves and fruits of cultivated conifers in Iran. Jundishapur J Nat Pharm Prod. 2013;8(3):113-7.

83. Sharma A, Joshi S, Kumar N. Antioxidant and antibacterial properties of leaves of Elaeocarpus sphaericus Roxb. And Pinus wallichiana from Uttarakhand region of India. International Journal of Green Pharmacy. 2015;9(4):246-51.

84. Rahman TU, Uddin G, Khattak KF, Liaqat W, Choudhary MI. Antibacterial, antifungal, insecticidal and phytotoxic activities of leaves of Pinus wallichiana. Journal of Chemical and Pharmaceutical Research. 2016;8(1):420-4.

85. Joshi S, Sati SC, Kumar P. Antibacterial potential and ethnomedicinal relevance of Kumaun Himalayan Gymnsoperms. The Journal of Phytopharmacology 2016;5(5):190-200. 


\section{GRAPHICAL ABSTRACT}

\section{Pinus wallichiana A.B. Jacks.}
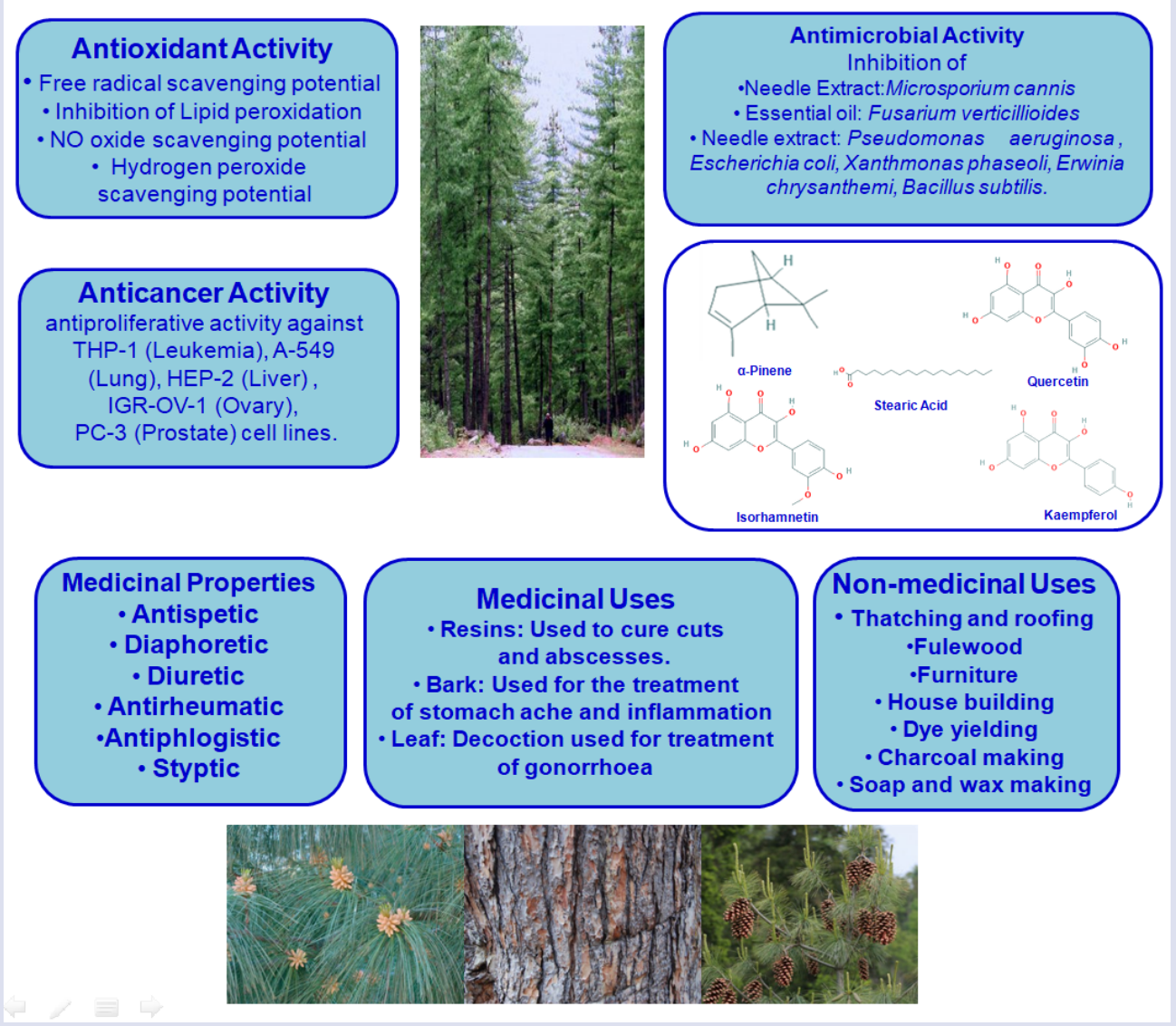

\section{ABOUT AUTHORS}

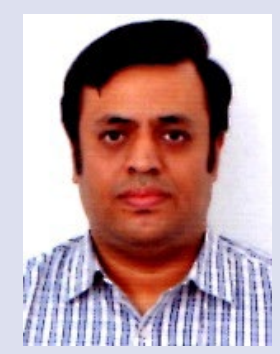

Dwaipayan Sinha: The author has done his graduation from prestigious Presidency University, Kolkata (then Presidency College) in Botany securing rank in University. He has done his masters from the esteemed department of Botany, University of Delhi, India with specialization in molecular biology and genetics. The author has done his doctorate from CSIR-Indian Institute of Toxicology Research, Lucknow, India on antioxidants using gymnosperm as model system. The author has more than 15 years research experience in gymnosperm, antioxidants, phytochemistry, plant natural products, nutraceuticals and Ethnobotany. The author has done extensive research in various gymnosperm belts of Indian Himalayas and has published several papers in peer reviewed journals. The author is a faculty in Department of Botany, Government General Degree College, Mohanpur, Paschim Medinipur under West Bengal Education Service, Government of West Bengal and has more than 10 years teaching experience to his credit.

Cite this article: Sinha D. A Review on Ethnobotanical, Phytochemical and Pharmacological Profile of Pinus wallichiana A.B. Jacks. Pharmacog J. 2019;11(4):624-31. 